УДК 616.36-002

DOI https://doi.org/10.11603/2312-0967.2019.2.10185

\title{
АНАЛІЗ СТРУКТУРИ ТА ДИНАМІКИ СОЦІАЛЬНО-МЕДИЧНИХ ПОКАЗНИКІВ ХРОНІЧНОГО ВІРУСНОГО ГЕПАТИТУ С В УКРАЇНІ
}

\author{
І. В. Кубарєва, А. В. Волкова, А. А. Ноздріна \\ Національний фрармацевтичний університет, Харків \\ socpharm@nuph.edu.ua
}

ІНФОРМАЦІЯ

Надійшла до редакції / Received: 21.05.2019

Після доопрацювання / Revised: 24.05.2019

Прийнято до друку / Accepted:

31.05.2019

\section{Ключові слова:}

хронічний гепатит C; поширення захворювання; структура захворювання.

\begin{abstract}
АНОТАЦІЯ
Мета роботи. Здійснити аналіз структури та динаміки соціально-медичних показників хронічного вірусного гепатиту С (ГС) в Україні.

Матеріали і методи. У дослідженні застосовано методи маркетингового аналізу, аналітичний, порівняльний методи та узагальнення інформації.

Результати й обговорення. За результатами аналізу визначено, що близько 75 \% випадків хронічного ГС у світі припадає на країни з низьким і середнім рівнями доходу. В Україні реєструють близька 47157 випадків на рік, частка ГС серед усіх захворювань в Україні складала у 2013 р.— 0,063 \%, у 2017 р. - 0,087 \% і має тенденцію до збільшення.

Наведено результати аналізу поширення ГС в Україні. Найбільш високі показники уЗапорізькійта Миколаївській областях. Розраховано середнійтемп приросту показників поширення, який склав 7,4 \% щорічно. Проаналізовано структуру вікового розподілу захворювання, так у період 2013-2017рр. на доросле населення припадало 98,78 \% від усіх випадків, 0,31 \% - на підлітків 15-17 років і 0,92 \% - на дітей від 0 до 14 років відповідно. Серед дітей віком 0-14 років визначено приріст випадків хронічного ГС на 13,25 \%. Висновки. Встановлено тенденцію зростання кількості випадків хронічного ГС в період 2013-2017рр., визначено виражене збільшення питомої ваги хронічного ГС серед усіх випадків захворювань України. В усіх регіонах спостерігається зростання кількості випадків даного захворювання. Особливу увагу слід приділити регіонам 3 високими показниками поширення та 3 високими темпами росту даного захворювання. Вакцини проти ГС не існує, отже, основні зусилля необхідно зосередити на профілактиці, діагностиці та лікуванні даного захворювання. У зв'язку з цим все більшої значущості набуває розробка шляхів вдосконалення комплексного надання якісної медичної та ефективної фрармацевтичної допомоги хворим на ГС.
\end{abstract}

Вступ. На сьогодні гепатит С (ГС) в усьому світі $\epsilon$ однією з найбільш значущих медико-соціальних проблем [1]. Вірусні гепатити - це глобальна загроза для здоров'я, котрій до недавнього часу не приділяли належної уваги.

За даними ВООЗ, вірусом ГС у світі інфріковано на даний момент близько 150-200 млн людей. Особли- вістю даного вірусу є те, що ГС дуже часто стає хронічним (в 70-75 \% випадків), й більшість людей навіть не підозрює, що хворі на ГС. Клінічні прояви спочатку мінімальні, проте згодом наслідки, до яких призводять гепатит, такі як хронічні ураження печінки, зокрема цироз, гепатоцелюлярна карцинома, значно погіршують якість життя людини [2]. За оцінками

ISSN 2312-0967. Pharmaceutical review. 2019. № 2 
ВОО3, близько 40 \% випадків цирозу печінки, 65 \% випадків раку печінки, а також близько $30 \%$ трансплантацій печінки у світі зумовлено саме наявністю ГС в анамнезі [3].

Останнім часом у фраховій літературі достатньо публікацій, присвячених наданню фрармацевтичної допомоги хворим на вірусні гепатити, що вказує на актуальність тематики. Велика увага приділяється дослідженню ринку противірусних препаратів, гепатопротекторів та фрармакоекономічному аналізу фрармакотерапії вірусних гепатитів. Цими питаннями займались багато українських та іноземних вчених [4-10]. Однак аналізу сучасних даних соціально-медичних показників хронічного ГС в динаміці не проводили.

3 огляду на вищезазначене, метою нашого дослідження став аналіз структури та динаміки соціальномедичних показників вірусного ГС в Україні з використанням методів порівняльного, логічного, математичного аналізів. Відповідно до визначеної мети сфрормульовано основні завдання дослідження, а саме:

- узагальнити фрактори ризику виникнення захворювання;

- $\quad$ здійснити аналіз даних щодо поширення ГС у світовій практиці;

- $\quad$ здійснити аналіз даних щодо поширення ГС в Україні;

- $\quad$ здійснити аналіз показників поширення хронічного ГС залежно від соціально-демографрічних характеристик.

Результати й обговорення. Відповідно до завдань дослідження, на першому етапі роботи ми проаналізовали фрактори, які підвищують ризик захворювання. Відомо, що вірус ГС має гемоконтактні шляхи передачі, тож в основному передається при контакті 3 інфрікованою кров'ю та рідше з біологічними рідинами інфрікованої людини. Іноді може відбуватися і вертикальний механізм передачі [11 ].

Так, використання нестерилізованих шприців після інфрікованої людини, побутових чи професійних приладів, переливання неперевіреної крові та її компонентів, незахищений статевий контакт - все це може призвести до зараження вірусом ГС. Оскільки на початку захворювання перебігає безсимптомно, і людина може довго навіть не підозрювати, що хвора на гепатит, то можна виділити такі основні групи населення, які мають підвищений ризик інфрікування вірусом ГС:

- особи, яким переливали кров та продукти крові в закладах охорони здоров'я (О3);

- працівники закладів О3;

- особи, які вживають ін'єкційні наркотичні лікарські препараті (внаслідок сумісного використання зараженого ін'єкційного обладнання та зараженій крові);

- особи, які відбувають покарання (і теж внаслідок спільного використання шприців);
- особи, які мають татуювання чи пірсинг;

- $\quad$ діти, які народилися від матері, яка інорікована вірусом ГС;

- особи, які мають сексуальних партнерів, інфрікованих вірусом ГС;

- особи із супутніми інфекціями, наприклад, гепатитом В разом із ГС, вірусним гепатитом та туберкульозом, ВІЛ та вірусним гепатитом.

На наступному етапі дослідження ми проаналізовали дані ВООЗ щодо поширення ГС у світі [12]. Встановлено, що найбільш поширене це захворювання у регіоні Східного Середземномор'я та Європейському регіоні ВОО3, де показники поширеності захворювання становлять 2,3 \% та 1,5 \% відповідно. В інших регіонах ВООЗ ці показники коливаються від 0,5 до 1,0 \% (рис. 1).

Більшість випадків інфрікування пов'язана 3 використанням небезпечних методів проведення ін'єкцій та інших медичних процедур [3]. Так, епідемії ГС, що пов'язують із застосуванням ін'єкційних наркотичних лікарських засобів, відмічаються в усіх регіонах. Згідно зі статистичними даними, майже $67 \%$ осіб, які приймають ін'єкційні наркотики, інфріковані вірусним ГС [1].

Дані щодо поширення ГС в Європейському регіоні ВООЗ різняться, так є дуже низькі показники поширеності, наприклад в країнах Північної, Західної та Центральної Європи, разом з тим достатньо високі - в країнах Південної та Східної Європи, Центральної Азії [3].

За результатами аналізу визначено, що близько $75 \%$ випадків хронічного ГС припадає на країни 3 низьким і середнім рівнями доходу. Так, за даними ВООЗ 2016 р., найбільша епідемія ГС була у Китаї (майже 10 млн людей, що живуть з вірусом ГС у 2015 р.), Пакистані (7,2 млн), Індії (6,2 млн) та Єгипті (5,6 млн); на ці чотири країни припадало майже 40 \% від всіх людей, які живуть з вірусом ГС [12].

На сьогодні вірусний гепатит став однією з основних причин смертей та інвалідності по всій земній кулі та знаходиться в одному ряду з туберкульозом, малярією та ВІЛ. У зв'язку з цим, ВООЗ прийняла Глобальну стратегію сектора охорони здоров'я по вірусному гепатиту 3 метою елімінації гепатитів до 2030 року і планує забезпечити діагностику 90 відсотків і необхідне лікування 80 відсотків носіїв вірусу гепатиту В або С до 2030 р. [1, 3].

На наступному етапі дослідження ми здійснили аналіз даних медичної статистики України за 20132017 рр. щодо чисельності хворих на ГС, які проживають у районі обслуговування закладів О3. Згідно 3 даними, у період аналізу в Україні було зареєстровано 235786 випадків хронічного ГС (табл. 1). У середньому було зареєстровано 47157 випадків на рік. Як показано у таблиці 1, порівняно із 2013 р. ми спостерігаємо збільшення кількості випадків даного захворювання.

ISSN 2312-0967. Фармацевтичний часопис. 2019. № 2 


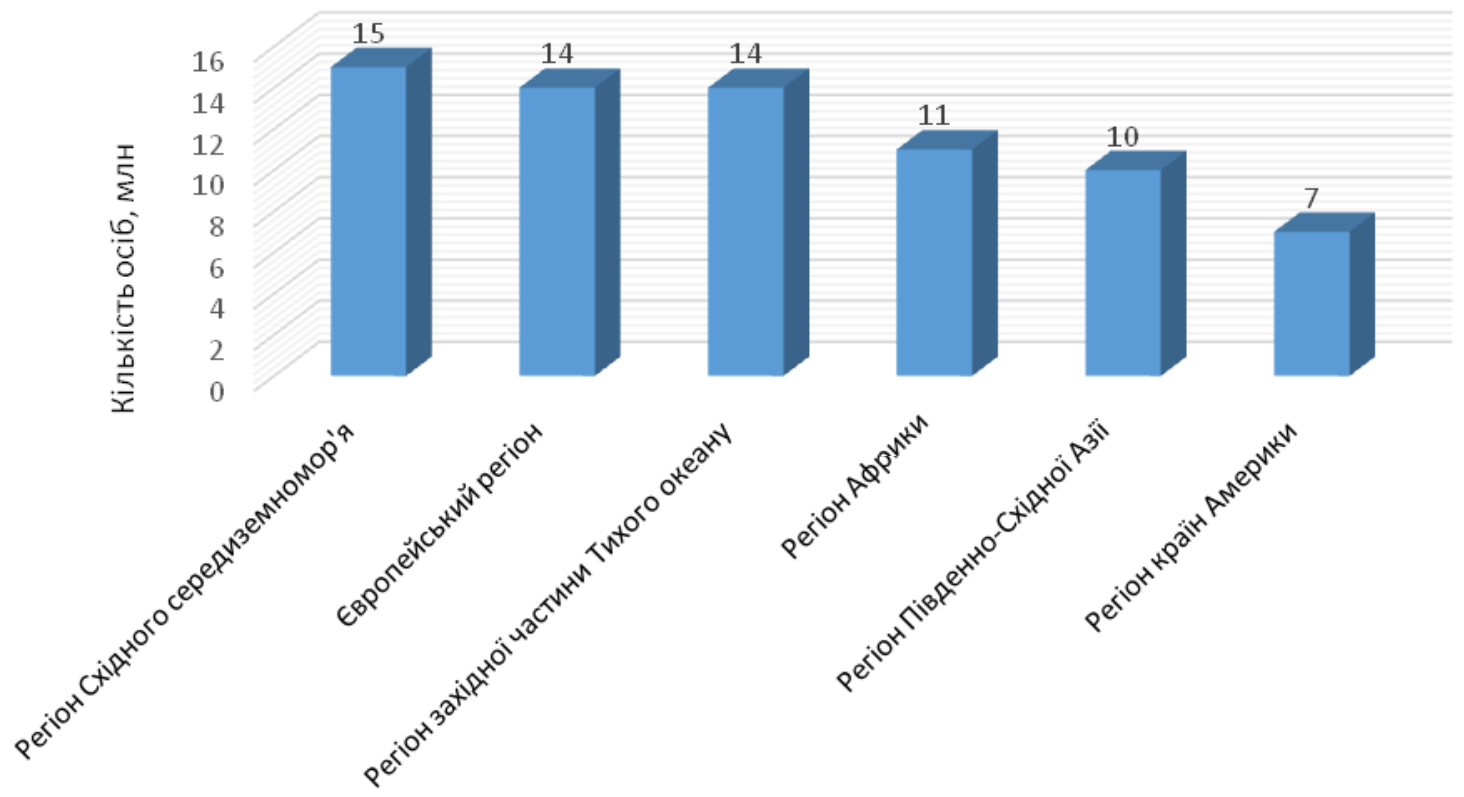

Рис. 1. Поширення гепатиту С в регіонах ВООЗ (за даними ВООЗ, 2017 р.) [1]

Таблиця 1

Кількість випадків хронічного ГС в Україні в період 2013-2017рр.

\begin{tabular}{|l|c|c|c|c|c|c|c|c|c|c|}
\hline & \multicolumn{3}{|c|}{ Роки } & Усього & \multicolumn{4}{c|}{ Приріст, \% } \\
\hline & 2013 & 2014 & 2015 & 2016 & 2017 & & $\begin{array}{l}2014 / \\
2013\end{array}$ & $\begin{array}{c}2015 / \\
2014\end{array}$ & $\begin{array}{c}2016 / \\
2015\end{array}$ & $\begin{array}{c}2017 / \\
2016\end{array}$ \\
\hline $\begin{array}{l}\text { Кількість } \\
\text { випадків, абс. } \\
\text { показники }\end{array}$ & 44088 & 43407 & 46883 & 48960 & 52448 & 235786 & $-1,54$ & 8,01 & 4,43 & 7,12 \\
\hline
\end{tabular}

У середньому частка ГС серед усіх захворювань України за 2013-2017 рр. склала менше 1 \%, а саме 0,075 \% (рис. 2). Ймовірно, що насправді ці показники вищі, бо в усьому світі і в Україні також реєструються випадки прихованого перебігу захворювання, коли воно виявляється лише при випадковому обстеженні. Як показано на рисунку 2, в період 20132017 рр. спостерігається тенденція до збільшення частки випадків ГС в структурі захворювань.

Враховуючи відмінні показники за областями України, ми провели ранжування і розподіл областей за групами з високим, середнім та низьким рівнем поширеності ГС. Проведено розрахунок довжини кроку за фрормулою:

$$
h=\frac{\max -\min }{n},
$$

де тах - максимальне значення показника поширеності;

min - мінімальне значення показника поширенос$\mathrm{Ti}$;

$n=3$ (кількість груп ).

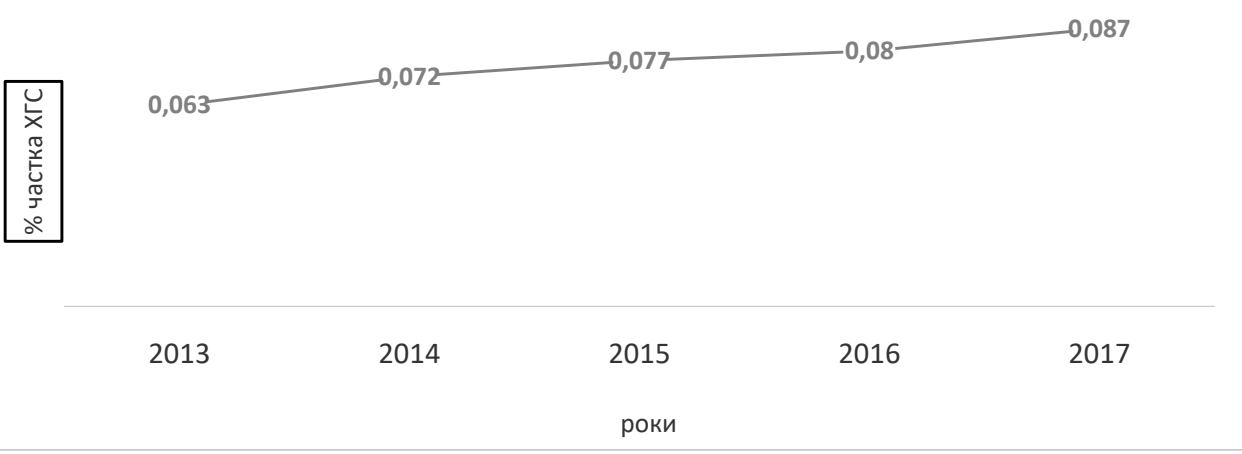

Рис. 2. Питома вага хронічного ГС серед усіх захворювань України.

ISSN 2312-0967. Pharmaceutical review. 2019. № 2 
За цією фрормулою довжина кроку склала 0,43 (випадків на 1000 осіб). Також ми проранжували за тією ж формулою регіони України за темпами приросту показників поширеності ГС. За проведеними розрахунками, довжина кроку склала 21,3.

За результатами аналізу встановлено зростання кількості випадків на усій території України. Аналіз даних МОЗ України щодо захворюваності показує нерівномірність поширення кількості хворих на хронічний ГС. Однак в усіх регіонах спостерігається зростання кількості випадків даного захворювання, тому дуже важливо вчасно аналізувати дані статистики, щоб мати можливість забезпечити сучасними ліками усіх пацієнтів з гепатитом С. Особливу увагу слід приділити регіонам з високими показниками поширення та темпами росту поширеності (табл. 2).

Далі ми вивчали показники поширення хронічного ГС в Україні з розбивкою за віком та статтю. Проаналізувавши дані центру медичної статистики МО3 України, встановлено, що у показниках на 100 тис. населення поширення хронічного ГС за 2013 2017 рр. у середньому дорівнювала 114 осіб на 100 тис. населення. У дітей віком 0-14 років цей показник склав 0,066 осіб на 1 тис. населення, у підлітків 1517 років - 118 осіб на 1 тис. населення.

У проаналізований період 2013-2017 рр. у дітей віком 0-14 років спостерігалось стабільне зростання показників поширення хронічного ГС, у підлітків 1517 років спостерігалось зменшення зростання показників поширення хронічного ГС. Серед дорослих відбулося зростання показників поширення хронічного ГС, середній темп приросту склав 7,4 \% щорічно. Якщо брати до уваги все населення країни, то з 2013 по 2017 рр. спостерігали значне зростання показників поширення хронічного ГС по Україні, в середньому щорічний приріст склав $7 \%$, насамперед, за рахунок дорослого населення.

У цілому, на хронічний ГС частіше хворіли дорослі, ніж діти - у середньому на доросле населення припадало 98,78 \% від усіх випадків, 0,31 \% — на підлітків 15-17 років і 0,92 \% - на дітей від 0 до 14 років. У таблиці 3 відображена тенденція до зменшення випадків хронічного ГС серед підлітків 15-17 років. Разом 3 тим, порівняно з 2017 р. із 2013 р. серед ді-

\section{Таблиця 2}

Результати аналізу поширення ГС в Україні

\begin{tabular}{|c|c|c|}
\hline & \multicolumn{2}{|c|}{ Адміністративно-територіальні об'єднання (області) } \\
\hline & Поширення ГС & Приріст показників поширення ГС \\
\hline Високий рівень & $\begin{array}{l}\text { Запорізька } \\
\text { Миколаївська }\end{array}$ & $\begin{array}{l}\text { Львівська } \\
\text { Харківська } \\
\text { Волинська } \\
\text { Чернівецька } \\
\text { Вінницька } \\
\text { Черкаська }\end{array}$ \\
\hline Середній рівень & \begin{tabular}{l}
\multicolumn{1}{c}{ 0,93-0,71 } \\
Кіровоградська, Дніпропетровська, \\
Київська \\
Одеська \\
Сумська \\
Полтавська \\
Рівненська
\end{tabular} & $\begin{array}{l}\text { Полтавська } \\
\text { Хм,04-29,85 } \\
\text { Хальницька } \\
\text { Закарпатська } \\
\text { Миколаївська } \\
\text { Херсонська } \\
\text { Тернопільська } \\
\text { Рівненська }\end{array}$ \\
\hline Низький рівень & $\begin{array}{l}\text { Херсонська } \\
\text { Черкаська } \\
\text { Вінницька } \\
\text { Чернігівська } \\
\text { Житомирська } \\
\text { Харківська } \\
\text { Донецька } \\
\text { Чернівецька } \\
\text { Хмельницька, Тернопільська } \\
\text { Львівська } \\
\text { Івано-срранківська } \\
\text { Закарпатська } \\
\text { Волинська }\end{array}$ & $\begin{array}{l}\text { 27,42-7,90 } \\
\text { Кіровоградська } \\
\text { Чернігівська } \\
\text { Сумська } \\
\text { Київська } \\
\text { Запорізька } \\
\text { Одеська } \\
\text { Івано-Франківська } \\
\text { Житомирська } \\
\text { Дніпропетровська }\end{array}$ \\
\hline
\end{tabular}

ISSN 2312-0967. Фармацевтичний часопис. 2019. № 2 
Таблиця 3

Структура вікового розподілу хворих на хронічний ГС

\begin{tabular}{|c|c|c|c|c|c|c|c|}
\hline \multirow{2}{*}{ Вікові категорії } & \multicolumn{5}{|c|}{ Питома вага у структурі поширення ГС } & \multirow{2}{*}{$\begin{array}{c}\text { Середне } \\
\text { значення,\% }\end{array}$} & \multirow{2}{*}{$\begin{array}{r}\text { Приріст, \% } \\
2017 / 2013 \\
\end{array}$} \\
\hline & 2013 & 2014 & 2015 & 2016 & 2017 & & \\
\hline $\begin{array}{l}\text { Діти віком 0-14 } \\
\text { років, \% }\end{array}$ & 0,83 & 0,89 & 0,96 & 0,95 & 0,94 & 0,92 & $+13,25$ \\
\hline $\begin{array}{l}\text { Підлітки віком } \\
\text { 15-17 років, \% }\end{array}$ & 0,40 & 0,37 & 0,30 & 0,26 & 0,20 & 0,31 & -50 \\
\hline $\begin{array}{l}\text { Дорослі віком } 18 \\
\text { років і старші, \% }\end{array}$ & 98,78 & 98,73 & 98,74 & 98,79 & 98,86 & 98,78 & $+0,08$ \\
\hline
\end{tabular}

тей віком 0-14 років спостерігається приріст випадків хронічного ГС на 13,25 \%. Серед дорослого населення цей приріст склав 0,08\%.

Також було встановлено, що на хронічний ГС частіше хворіють особи чоловічої статі. За період аналізу 2013-2017 рр. у середньому співвідношення склало 43,76 \% (жінки): 56,74 \% (чоловіки).

Таким чином, проведене дослідження структури та динаміки соціально-медичних показників хронічного ГС показало, що за період 2013-2017 рр. спостерігалося стабільне зростання випадків та показників поширення ГС. Тому потрібно приділити особливу увагу профрілактиці, ранній діагностиці та вчасному лікуванню. Важливо забезпечити доступ хворим до ефрективної противірусної терапії.

Висновки. За результатами аналізу структури та динаміки соціально-медичних показників хронічного вірусного ГС в Україні встановлено стабільну тенденцію збільшення кількості випадків хронічного ГС, виражене збільшення питомої ваги хронічних ГС серед усіх випадків захворювань України.

Випадки захворювання хронічного ГС частіше фріксуються серед дорослих (98,78 \%) та осіб чоловічої статі.
У віковій групі підлітків 15-17 років спостерігається тенденція до зменшення кількості випадків хронічного ГС.

Оскільки значна кількість інфрікованих осіб не обізнані щодо своєї хвороби через мінімум клінічних проявів протягом тривалого часу, актуальним $\epsilon$ підвищення уваги до ранньої діагностики вірусу ГС.

Результати проведених досліджень $є$ важливими для вдосконалення напрямків оптимізації фрармацевтичного забезпечення хворих на хронічний ГС. Перспективним напрямом також вважаємо вивчення доступності лз для вказаної категорії населення.

Вірусний ГС на сьогодні становить серйозну загрозу для здоров'я, тому для еорективної боротьби з ГС треба вживати комплексні заходи: підвищувати рівень обізнаності населення, приділяти більше уваги профрілактиці передачі вірусу ГС, бути пильними до тих груп населення, які мають найбільший ризик інфрікування.

Конфрлікт інтересів: відсутній.

Conflicts of interest: authors have no conflict of interest to declare.

\section{АНАЛИЗ СТРУКТУРЫ И ДИНАМИКИ СОЦИАЛЬНО-МЕДИЦИНСКИХ ПОКАЗАТЕЛЕЙ ХРОНИЧЕСКОГО ВИРУСНОГО ГЕПАТИТА С В УКРАИНЕ}

\section{И. В. Кубарева, А. В. Волкова, А. А. Ноздрина}

Национальный фрармацевтический университет, Харьков

socpharm@nuph.edu.ua

Цель работы. Проанализировать структуру и динамику социально-медицинских показателей хронического вирусного гепатита С (ГС) в Украине.

Материалы и методы. В исследовании использованы методы маркетингового анализа, аналитический, сравнительный методы, а также обобщения инорормации.

Результаты и обсуждения. По результатам анализа выявлено, что около 75 \% случаев хронического ГС в мире приходится на страны с низким и средним уровнями дохода. В Украине регистрируется приблизительно 47157 случаев в год, удельный вес ГС среди всех заболеваний Украины составил в 2013 г.— 0,063 \%, в 2017 г.- 0,087 \% и имеет тенденцию к возрастанию.

Приведены результаты анализа распространенности ГС в Украине. Наиболее высокие показатели отмечаются в Запорожской и Николаевской областях. Рассчитан средний темп прироста показателей распространенности, который составил 7,4 \% ежегодно. Проанализирована структура возрастного распределения заболевания, так в

ISSN 2312-0967. Pharmaceutical review. 2019. № 2 
период 2013-2017 гг. на взрослое население приходилось 98,78 \% всех случаев, 0,31\% - на подростков 15-17 лет и 0,92 \% - на детей від 0 до 14 лет соответственно. Среди детей в возрасте 0-14 лет определен прирост случаев хронического ГС на $13,25 \%$.

Выводы. Установлена тенденция увеличения количества случаев хронического ГС в период 2013-2017 гг., определено существенное увеличение удельного веса хронического ГС среди всех заболеваний Украины. Во всех регионах наблюдается рост количества случаев данного заболевания. Особенное внимание следует уделить регионам с высокими показателями распространенности и с высокими темпами роста распространенности данного заболевания. Вакцины от ГС не существует, следовательно основные усилия должны быть направлены на профилактику, диагностику и лечение данного заболевания. В связи с этим все большее значение приобретает разработка путей усовершенствования комплексного оказания качественной медицинской и эффективной фрармацевтической помощи больным ГС.

Ключевые слова: хронический гепатит С; распространенность заболевания; структура заболевания.

\section{ANALYSIS OF STRUCTURE AND DYNAMICS OF SOCIO-MEDICAL INDICATORS OF CHRONIC VIRAL HEPATITIS C IN UKRAINE}

\section{V. Kubarieva, A. V. Volkova, A. A. Nozdrina}

National University of Pharmacy, Kharkiv

socpharm@nuph.edu.ua

The aim of the work. To analyze the structure and dynamics of social and medical indicators of chronic viral hepatitis $\mathrm{C}$ $(\mathrm{HC})$ in Ukraine.

Materials and Methods. The methods of marketing analysis, analytical, comparative methods and generalization of information were used in the research.

Results and Discussion. The analysis have revealed that about $75 \%$ of chronic global HC cases occur in low and middle income countries. About 47157 cases per year are registered in Ukraine, the share of HC among all diseases in Ukraine was in $2013-0.063 \%$, in $2017-0.087 \%$ and tends to increase. The results of the analysis of the prevalence of HC in Ukraine are presented. The highest rates are observed in Zaporizhia and Mykolaiv regions. The average rate of increase in prevalence rates was calculated, which was $7.4 \%$ annually. The structure of the age distribution of the disease is analyzed, so in the period 2013-2017, the adult population accounted for $98.78 \%$ of all cases, $0.31 \%$ for teenagers $15-17$ and $0.92 \%$ for children from 0 to 14 years, respectively. Among children aged 0-14 years, an increase in cases of chronic HC was detected in $13.25 \%$.

Conclusions. There is a tendency to increase the number of cases of chronic HC in the period of 2013-2017, a pronounced increase in the proportion of chronic $\mathrm{HC}$ is detected among all cases of the disease in Ukraine. In all regions there is an increase in the number of cases of this disease. Particular attention should be paid to regions with high prevalence rates and high rates of prevalence of this disease. Vaccines against $\mathrm{HC}$ do not exist, so the main efforts should be directed towards the prevention, diagnosis and treatment of the disease. In this regard, the development of ways to improve the integrated provision of high-quality medical and effective pharmaceutical care for HC patients is becoming increasingly important.

Key words: chronic hepatitis C; disease prevalence; structure of the disease.

\section{Список літератури}

1. Світова статистика охорони здоров'я 2018 [Електронний ресурс]. - Режим доступу : https://www. who.int/gho/publications/ world_health_statistics/2018/ en/

2. Расширяя возможности лечения гепатита С / А. Муртузаоглы, О. А. Голубовская, П. Буггиш [и др.] // Здоров'я України. - № 3. - 2017. - С. 14-15.

3. Всесвітній саміт Гепатиту [Електронний ресурс]. Режим доступу : http://www.worldhepatitissummit.org/

4. Голубовська О. А. Невирішені проблеми та нові горизонти в лікуванні хронічного гепатиту C I О. А. Голубовська // Гепатологія. - 2015. - № 4. C. 7-15.
5. Громова Н. И. Роль хронических вирусных гепатитов в формировании цирроза печени и гепатоцеллюлярной карциномы / Н. И. Громова // Иммунопатология, аллергология, иноректология. 2012. - № 1. - C. 27-44.

6. Динник Н. В. Актуальні питання етіології, патогенезу та клініки хронічного вірусного гепатиту С / Н. В. Динник // Клінічна медицина. - 2012. № 2. - С. 73-78.

7. Котвіцька А. А. Фармакоекономічний аналіз терапії хворих на гепатит С / А. А. Котвіцька, О. А. Пастухова, М. В. Люшенко // Формування Національної лікарської політики за умов впровадження медичного страхування: питання освіти, теорії та практики :

ISSN 2312-0967. Фармацевтичний часопис. 2019. № 2 
матеріали IV Всеукр. наук.-практ. конор., м. Харків, 15 берез. 2017 р. - Х., 2017. - С. 198.

8. Федяк І. О. Фармакоекономічні підходи до вдосконалення лікарського забезпечення хворих на хронічні вірусні гепатити в Україні / І. О. Федяк : авторефр. дис. канд. фрармац. наук : 15.00 .01 технологія ліків, організація фрармацевтичної справи та судова фрармація; НМАПО ім. П. Л. Шупика. - К., 2011. - 23 c.

9. Котвіцька А. А. Дослідження соціально-економічних складових надання фрармацевтичної допомоги хворим, які потребують трансплантації печінки / А. А. Котвіцька, А. В. Волкова, І. В. Горецька // Соціальна фрармація в охороні здоров'я. - 2017. T. 3, № 2. - C. 41-48. DOI: 10.24959/sphhcj.17.80
10. Романько Т. А. Аналіз територіальної локалізації суб'єктів господарської діяльності фармацевтичного сектора галузі охорони здоров'я України / Т. А. Романько, Ю. В. Корж, С. Г. Калайчева // Соціальна фрармація в охороні здоров'я. - 2018. - Т. 4, № 4. C. 50-57. DOl:https://doi.org/10.24959/sphhcj.18.137

11. Фітькало О. С. Хронічний гепатит С як наслідок наркоманії / О. С. Фітькало, Т. В. Покровська // Гепатологія. - 2016.- № 3. - С. 51-57.

12. ВОО3 World Health Organization [Електронний ресурс]. - Режим доступу :http://www.euro.who.int/ en/health-topics/communicable-diseases/hepatitis/ publications/2017/action-plan-for-the-health-sectorresponse-to-viral-hepatitis-in-the-who-european-region-2017

Ukrainian

8. Fediak IO [Pharmacoeconomic approaches to improving the medical provision of chronic viral hepatitis patients in Ukraine]. Candidate's Extended Abstract. Kyiv; 2011. Ukrainian.

9. Kotvitska AA, Volkova AV, Horetska IV. [The study of socio-economic components of providing the pharmaceutical care to liver transplantation patients]. Sotsialna farmatsiia v okhoroni zdorovia. 2017;3: 41-8. Ukrainian. DOI: 10.24959/sphhcj.17.80

10. Romanko TA, Korzh luV, Kalaycheva SH. [Analysis of territorial localization of subjects of the economic activity of the pharmaceutical sector of the healthcare branch in Ukraine]. Sotsialna farmatsiia $v$ okhoroni zdorovia. 2018;4: 50-7. Ukrainian. DOI: https://doi.org/10.24959/ sphhcj.18.137

11. Fitkalo OS, Pokrovska TV. [Chronic hepatitis C as a consequence of addiction]. Hepatolohiia. 2016;3: 51-7. Ukrainian.

12. World Health Organization. [Electronic resource, Geneva]. Available from: http://www.euro.who.int/en/healthtopics/communicable-diseases/hepatitis/publications/2017/action-plan-for-the-health-sector-responseto-viral-hepatitis-in-the-who-european-region-2017

\section{Відомості про авторів:}

Кубарєва І. В. - канд. фрармац. н., доцент кафедри соціальної фрармації, проректор з науково-педагогічної роботи, Національний фрармацевтичний університет, Харків, Україна. E-mail: socpharm@nuph.edu.ua, ORCID 0000-0001-6617-2575 Волкова А. В. - канд. фрармац. н., доцент кафедри соціальної фрармації, завідувач кафедри соціальної фрармації, Національний фрармацевтичний університет, Харків, Україна. E-mail: volkova.nfau@gmail.com, ORCID 0000-00032781-5407

Ноздріна А. А. - асист. кафедри соціальної фармації, Національний фрармацевтичний університет, Харків, Україна. E-mail: Almira.nozdrina@gmail.com, ORCID 0000-0003-2472-4540

Information about the authors:

Kubarieva I. V. - PhD (Pharmacy), Associate Professor of the Social Pharmacy Department, the first vice-rector for academic work, National University of Pharmacy, Kharkiv, Ukraine. E-mail: socpharm@nuph.edu.ua, ORCID 0000-0001-6617-2575

Volkova A. V. - PhD (Pharmacy), Associate Professor of the Social Pharmacy Department, Chief of the Social Pharmacy Department, National University of Pharmacy, Kharkiv, Ukraine. E-mail: volkova.nfau@gmail.com, ORCID 0000-0003-2781-5407

Nozdrina A. A. - assistant of the Social Pharmacy Department, National University of Pharmacy, Kharkiv, Ukraine. E-mail: Almira.nozdrina@gmail.com, ORCID 0000-0003-2472-4540

ISSN 2312-0967. Pharmaceutical review. 2019. № 2 